\title{
Market Segmentation of Industry-Education Partnership Classes
}

\author{
Dwi Kartikasari \\ Dept. of Management and Business, Politeknik Negeri Batam, Indonesia \\ dwi@polibatam.ac.id
}

\begin{abstract}
Batam State Polytechnic opened industry-education partnerships classes in 2015. Because they were relatively new, the management of Batam State Polytechnic did not have the right marketing strategy to attract prospective students for this class, consequently, the number of recruited students did not meet the quota provided and the number of applicants was still far below the number of applicants on other campuses. The management of Batam State Polytechnic was forced to open more than two batches of recruitment although this action caused a delay to academic activities. The author believed Batam State Polytechnic failed in formulating its marketing strategy so that the attractiveness of partnership class did not reach the right market segment. Data collection was done through survey and documentation study on registration file of all students of cooperation class at Batam State Polytechnic using census sampling. This data were analyzed quantitatively using cluster analysis using K-means cluster with SPSS program. The cluster result was used to know the segmentation of the largest market. This study found that the largest segment has the following characteristics: (1) have a home address in Batam; (2) come from public senior high school; (3) study non aviation majors in high school; (4) come from high school in Batam; and (5) age when entering college 18-19 years. Thus, marketing strategy should focus on this group via promotion to some significant schools in Batam. Promotion via newspaper is less effective than official website and word of mouth. Promotion should begin as soon as possible as this action will attract more prospective students.
\end{abstract}

Keywords: market segmentation, industry-education partnership

\section{INTRODUCTION}

Economic growth has a positive correlation to growth in the number of air passengers which eventually leads to a significant growth of aircraft maintenance industry. Unfortunately, the growth of Indonesia's air transport industry has been hindered by the lack of human resources in air transport sector, particularly mechanics. PT GMF AeroAsia predicts the ratio between the demand and the supply of aircraft mechanics around 3 to 1. In 2015, PT GMF AeroAsia needs approximately 1500 newly-hired technicians whereas higher education and training facilities can only supply 600 graduates each year (Kartikasari and Sanyoto, 2015).

In order to bridge the gap, PT GMFAeroAsia collaborates with ten universities, including Batam State Polytechnic (Polibatam), so that partner universities can adopt aircraft maintenance curriculum that has become the industry standards into their education system. Maintenance Repair Overhaul (MRO) industry working together with universities is very common across the globe. This cooperation has been proven increasing manpower supply for the industry and improving the reputation of the universities. Our neighbor countries, Malaysia and Singapore, for example, have Polytechnic Banting, Selangor working together with Malaysia Airlines and Singapore Polytechnic with Singapore Airlines.

In 2014, Batam State Polytechnic and PT GMF AeroAsia has signed a memorandum of understanding to collaborate to improve the competitiveness of both parties by opening one partnership class per year. In 2015, the first class was opened to public. This class is under aeronautical concentration in mechanical engineering department. PT GMF AeroAsia and Batam State Polytechnic have worked together since the process of recruitment of students. The students of this class are considered PT GMF AeroAsia's employees, thus they signed employment contracts before starting their education at Batam State Polytechnic. In Indonesia, schools with official ties to some employers are always attractive because they offer a guaranteed placement to students once they graduate.

However, the management of Batam State Polytechnic faced contadictory facts. Despite extra promotion through newspapers, the number of applicants was still far below the number of applicants on other campuses. Consequently, the number of recruited students did not meet the quota provided by the industry. The management of Batam State Polytechnic was forced to open more than two batches of recruitment although this action caused a delay to academic activities. Thus, the consequences were severe.

When the author stepped back and reflected, she believed that the partnership program was certainly attractive. But, the author thought that Batam State Polytechnic failed in formulate its marketing strategy so that this attractiveness did not reach the right market segment. Thus, it is very important for the management of Batam State Polytechnic to have the right marketing strategy to attract prospective students for this special class.

The marketing strategy for this special class is alleged to be very different from the marketing strategy for regular classes or trainings, as this class is indicated to have a different market segment than other classes. Aspects to consider in the management of this class are also different, both in terms of managing expectations of third parties (PT GMF AeroAsia) and expectations of students and their parents.

Until now, the students of partnership class are not only women but also men, not only from Kepri, but also other areas in Java or Sumatera Island. They come from the all majors of senior high school, either aviation or non aviation. Some have special relation with PT GMF AeroAsia and some not. Therefore, market segmentation is needed to group the heterogeneous market into a homogeneous market group based on geography, demography, psychography and behavior factors. The basis for segmentation considerations needs to be carefully chosen to 
represent all parts of the market. After segmentation is done, then the target market can be set so that marketing is more focused on the potential market.

\section{METHODS}

Marketing research firms and researchers in market segmentation usually use the following steps (Kotler, 2003). The first step is survey, where researchers conduct interviews to seek explanations to gain an understanding of the motivation of consumer attitudes and behavior. Using this discovery, researchers prepare an official questionnaire to collect data on: their attributes and importance ratings, brand awareness and brand ratings, patterns of product usage and attitudes towards product categories; geographic, demographic, psychographic and mediagraphic respondents.

The next step is to perform factor analysis to remove the highly-correlated variable(s). Then the researcher applies a cluster analysis to produce the maximum number of different segments. Furthermore, the third step is the stage of formation in which each group is formed based on differences in attitude, behavior, demographics, psychographic and media patterns. Each segment can be named based on the distinguishing dominant traits. After evaluating different segments, the company can consider five patterns of target market selection (Kotler, 2003).

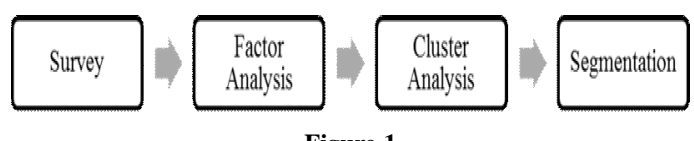

Figure 1

Steps of Segmentation Research (Kotler, 2003)

The effective segment profile should have the following information include size, purchasing power, and measurable segment profiles. Large and profitable segments are the ones to be served. The largest homogeneous group should be served by a tailor-made marketing program so this segment can be reached and served effectively (Kotler, 2003).

Table 1

Operational Definition of Research Variables

\begin{tabular}{lll}
\hline \multicolumn{1}{c}{ Dimension } & & \multicolumn{1}{c}{ Indicator } \\
\hline Demography & 1. & Age \\
& 2. & Gender \\
& 3. & Place of born \\
& 4. & Religion \\
& 5. & Place of senior high school \\
& 6. & Senior high school (private/public) \\
& 7. & Senior high school (aviation/not) \\
& 8. & Year of graduation \\
9. & Have lived in Batam before/not \\
Behavior & Psychography \\
& 1. & Access to information sources \\
& 2. & Recruitment test on other campuses \\
& 3. & Reasons for choosing Polibatam \\
& 4. & Reasons for choosing partnership class \\
5. & Willing to recommend partnership class \\
\hline Source: Adopted Elfinur and Restuti (2015); Kartikasari (2014)
\end{tabular}

Data collection is done through survey and documentation study on registration file of all students of cooperation class at Batam State Polytechnic. Thus, the sampling technique used in surveying and documentation studies is a census. The data were then analyzed quantitatively using cluster analysis using Kmeans cluster with SPSS program. The cluster result will be used to know the segmentation of student market based on a priori and post hoc approach. A priori approach can generally be extracted from registration data. While the post hoc approach using questionnaire instruments with the following variables (Table 1).

\section{RESULTS AND DISCUSSION}

To process binary data, first, the author standardized the data. Furthermore, the data were transformed into the scale type data, because she used the K-Means Cluster analysis. Using post hoc data, she extracted five significant factors to mention in the segmentation analysis out of 9 variables, namely: home address (Batam [1] and non Batam [0]), Public (1) or private (2), high school major aviation (1) and non aviation (0), place of origin of high school Batam (1) and non Batam (0), and age when entering college. The colors in Fig. 2 are arranged accordingly.

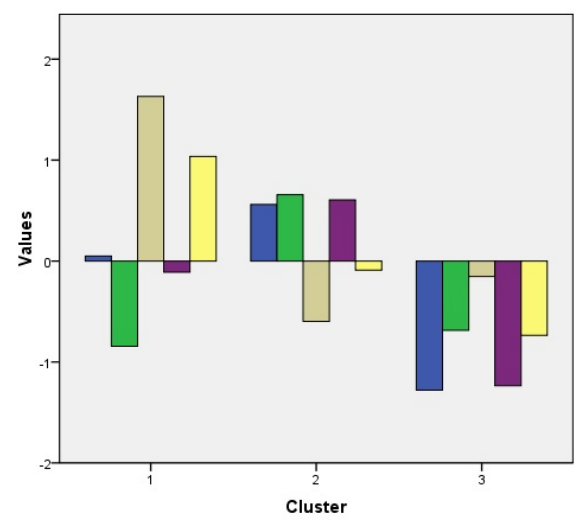

Figure 2

Cluster of Market Segmentation

The number of cases in each cluster is 9 cases for cluster 1, 22 cases for cluster 2, and 10 cases for cluster 3. Thus, the largest segment is from the middle/central/second segment, with the following characteristics: have a home address in Batam, come from public senior high school, study non aviation majors in high school, come from high school in Batam, age when entering college 18-19 years. Although the partnership class uses a recruitment system that applies across provinces as it uses GMF standards, and quite a lot of partnership class students come from out of Batam, but the management of the Batam State Polytechnic still needs to focus by recruiting from Batam rather than outside Batam. The percentage of number of partnership class students who come from outside Kepri province, such as Jakarta, East Java, West Java, Yogyakarta, Pontianak, Bengkulu, Bandung, North Sumatra, South Sumatra, West Sumatra, Aceh, and Riau, when compared with those from inside Kepri province is 30 percent. 


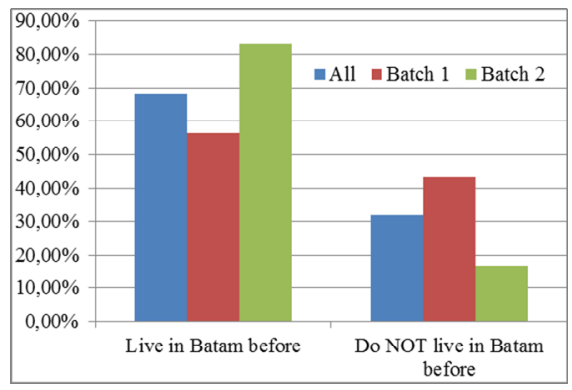

Figure 3

Students have Lived in Batam before College

Most students come from inside Batam. The number of students coming from outside Batam decreased in the second batch, where the proportion of local students increased. This may be due to the breakup of provincial government cooperation with Unsurya, so many local students are looking the only alternative in Batam, that is Batam State Polytechnic. Thus, to be frank, the main reason students of the partnership class choose Polibatam, not because of its reputation, but because of its proximity.

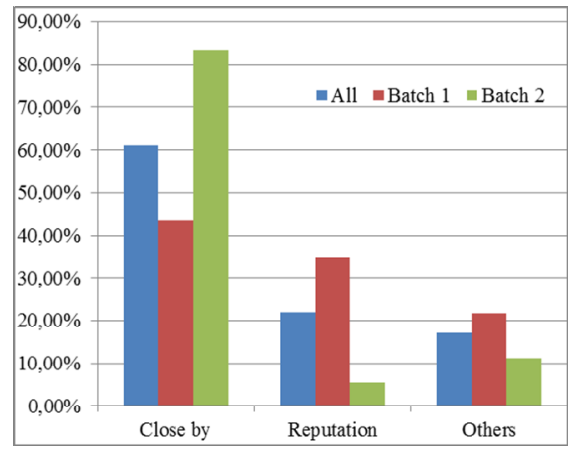

Figure 4

Students' Main Reasons of Choosing Partnership Class at Batam State Polytechnic

Reputation is not students' main concern. As long as they can get what they want in their proximity, they are slightly less concerned whether the institution is reputable or not. What they mostly want are two things, employment guarantee and basic license to work with aircraft.

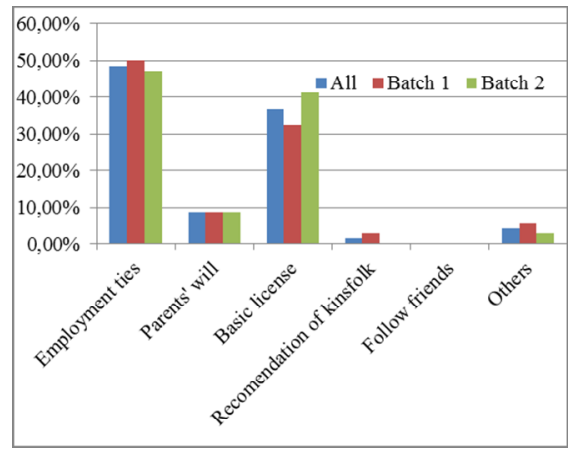

Figure 5

Students expectation out of partnership class
Fig. 5 shows that students already understand in advance about the partnership class program. They do not just follow their friends like students from other majors, but they aim for employment and basic license that accompanies students when graduating. Although quite a lot of students come from private high school and from aviation major, but until now, the largest compositions are students who come from public high schools in Batam and non aviation majors. Thus, socialization to public high schools should remain a priority.

The author lists the students' high school origin and finds that they mostly come from SMK1 Batam, SPAN Batam, SMAN 1 Batam, and SPN Bengkong. These are schools that are consistently sending prospective students to partnership class in addition to SMAN 4 Batam which this year sending the most students to the partnership class. Thus, marketing and socialization strategy should include at very least these schools because not only they have good track records but also their graduates are proven to fit the selection criteria of the recruitment of partnership class program.

Although many college-age students are waiting for the following year to take the exams again, most students come from the same year of graduation to get an entry ticket. Thus, promotion and socialization will be most effective to schools rather than via newspaper that target common market. Most of the students have not taken other campus test because the exam of partnership class in Polibatam is considered as among the first or the earliest so that many prospective students from outside the city take examination in Polibatam. Thus, the Polibatam recruitment that starts early should be maintained. The official website of Polibatam is the most widely accessed information media by prospective students compared to paid media such as brochures and newspapers. Fig. 7 below shows the details.

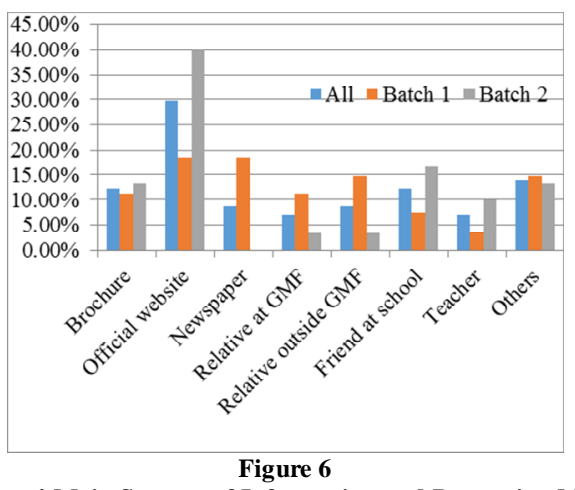

Students' Main Sources of Information and Promotion Media

The figure above underlines the importance of informal media, such as word of mouth from relatives, friends, teachers, or others who play a significant role in selecting the partnership class. The author argues that because the aviation industry is relatively narrow and niche market, then the promotion should be strengthened by word of mouth rather than common media like newspaper. In addition, the students' desire to recommend the partnership class is also very strong. 


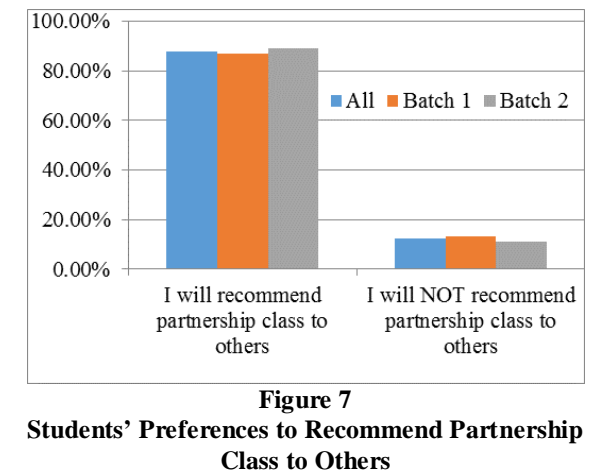

The students are proud of studying in this special class. This pride motivates them to recommend this program to others. The students can be beneficial resource for marketing the partnership program. The concept of market segmentation was first introduced by Wendell R. Smith in 1956 (Quelch and Jocz, 2008). According to Smith, consumers are unique and different. Consequently, they need different marketing programs. The company that decides to operate in a wide market realizes that it usually can not serve all the customers in that market. Customers are too numerous, scattered, and vary in their purchase requirements. Some competitors will be in a better position to serve a certain segment of the market. Market segmentation is a heterogeneous market-dividing activity of a product into market units (market segments) that are homogeneous (Dharmmesta, 1998).

Basically market segmentation is an activity of classifying heterogeneous markets into homogeneous so that the company can know which segment will be selected, so that the company can effectively and efficiently work on the market in accordance with the resources it has. The market segmentation approach helps companies provide a deeper understanding of consumers, enabling rapid detection of trends in rapidly changing markets, enabling them to evaluate competitive strengths and corporate weaknesses in competition, allowing for more systematic planning of marketing on the right media for the most potential segment (Mikhriani, 2012).

The bases for market segmentation include geography, demography, psychography, and behavior (Kotler, 2003). Geographic segmentation calls for the division of markets into different geographical units, such as country, state, territory, province, city, or RT. Companies may decide to operate within one or more geographical areas or operate within the entire region but pay attention to local variations in geographic needs and preferences.

Furthermore, the market segmentation can be determined based on demographic considerations. This demographic segmentation comprises and divides the market into groups based on demographic variables such as age, sex, income, occupation, and education. Market segmentation can be done with psychographic considerations. In this psychographical segmentation buyers are divided into different groups based on social class, lifestyle, personality. Furthermore, market segmentation can be done with consideration of consumer behavior. In behavioral segmentation, buyers are divided into groups based on their knowledge, attitude, usage or responses to a product (Kotler, 2003).

The basis of segmentation can be divided into two, namely a priori and post-hoc approach (Kasali, 1998). A priori segmentation can be built through geographic, demographic, and psychographic approaches. While post-hoc segmentation is built through behavioral approaches where researchers look for similar consumer groups in terms of how they behave, what they think, want or know, and / or other combinations of variables such as socio-economicdemography. Post-hoc segmentation is done after the marketing activities are completed based on actual consumers' characteristics. In the marketing process, segmentation does not stand alone. Segmentation is a unity with targeting and positioning, or often known as the abbreviation STP (segmenting, targeting, positioning). Here's an overview of the main stages in STP.

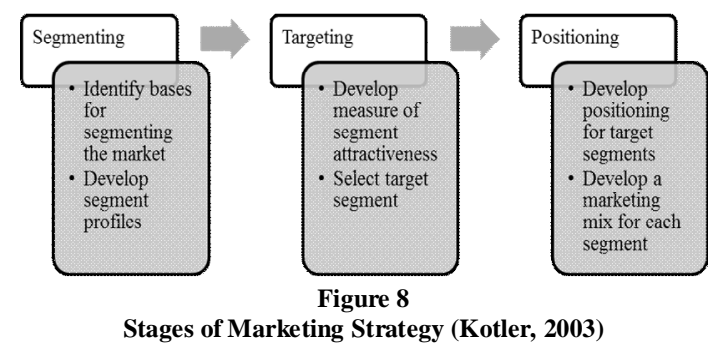

Targeting is an evaluation of a prominent segment, then evaluates one or more prominent segments. Positioning the market is to make a competitive position of the product and create an ideal marketing mix. STP is a set of marketing strategies, where segmentation is the basis for the next strategy, namely targeting and positioning. Segmentation is useful for improving the company's competition position and providing better service needs to consumers. It can increase sales, increase market share, and raise the reputation of the organization (Triatmanto, 2011).

\section{CONCLUSION}

Batam State Polytechnic has just opened industry-oriented classes in 2015. These classes have special curricula that are tailored in accordance with industry needs. These classes are manifestation of industry-education partnerships for mutual benefits. Because they are relatively new, the management of Batam State Polytechnic does not have the right marketing strategy to attract prospective students for this class, consequently, the number of recruited students does not meet the quota provided and the number of applicants is still far below the number of applicants on other campuses. The management of Batam State Polytechnic was forced to open more than two batches of recruitment although this action caused a delay to academic activities. Thus, the consequences were severe. 
The author believes that the partnership program is certainly attractive. But, she thinks that Batam State Polytechnic has failed in formulate its marketing strategy so that this attractiveness did not reach the right market segment. Large and profitable market segments are the ones to be served. Data collection is done through survey and documentation study on registration file of all students of cooperation class at Batam State Polytechnic. Thus, the sampling technique used in surveying and documentation studies is a census. The data were then analyzed quantitatively using cluster analysis using K-means cluster with SPSS program. The cluster result is used to know the segmentation of the largest market.

This study found that the largest segment has the following characteristics: (1) have a home address in Batam; (2) come from public senior high school; (3) study non aviation majors in high school; (4) come from high school in Batam; and (5) age when entering college 18-19 years. Thus, marketing strategy should focus on this group. This group can be reached via promotion and socialization to some significant schools in Batam, namely SMK 1 Batam, SPAN Batam, SMAN 1 Batam, SPN Bengkong, and SMAN 4. Promotion via newspaper is less effective than official website and word of mouth. Promotion should be concentrated in Batam, as the biggest market segment is in Batam. Socialization outside Batam is less necessary because prospective students are well aware of official website. Promotion should be maintained to begin as soon as possible as this action will attract more prospective students.

\section{REFERENCES}

[1] Dharmmesta, B. S. 1998. Marketing Principles: Asasasas Marketing. Yogyakarta: Liberty.

[2] Elfinur, \& Restuti, S. 2015. Market Segmentation Analysis Based on Demographics and Behavior Based on Benefits of Credit Customers PT BPR Mitra Rakyat Riau Pekanbaru City (Analisis Segmentasi Pasar Berdasarkan Demografis dan Perilaku Didasarkan Manfaat pada Nasabah Kredit PT BPR Mitra Rakyat Riau Kota Pekanbaru). Jurnal Tepak Manajemen Bisnis, 7(1), 1-18.

[3] Kartikasari, D., \& Sanyoto, P. E. 2015. Recognition of Prior Learning Breakthrough in Aircraft Maintenance Curriculum. Proceeding of Ocean, Mechanical and Aerospace-Science and Engineering, 2, 1-5

[4] Kartikasari, D. 2014. Gap Analysis Between Inputs With Outputs in Higher Education Accounting in Batam (Analisis Kesenjangan antara Input dengan Output pada Pendidikan Tinggi Akuntansi di Batam). National Seminar on Akuntansi Vokasi, Politeknik Negeri Padang, 12-13 June.

[5] Kasali, R. 1998. Targeting Indonesian Market: Segmentation, Targeting, and. Positioning (Membidik Pasar Indonesia: Segmentasi, Targeting, dan. Positioning). Jakarta: PT Gramedia Pustaka Utama.

[6] Kotler, P. 2003. Marketing Management. Jakarta: Prenhallindo.

[7] Mikhriani. 2012. Analysis of Facial Skin Care Market Segmentation Natasha Skin Care Yogyakarta (Analisis Segmentasi Pasar Perawatan Kulit Wajah Natasha Skin Care Yogyakarta). Jurnal Dakwah, 13(1), 105136.
[8] Thoyib, U. 2004. Manajemen Perdagangan Eceran. Yogyakarta: Ekonisia Universitas Islam Indonesia.

[9] Triatmanto, B. 2011. Analysis of Considered Factors in Market Segmentation Based on Benefit and Preference in Insurance Company in Malang (Analisis Berbagai Faktor yang Dipertimbangkan dalam Melakukan Segmentasi Pasar berdasarkan Benefit dan Preferensi pada Perusahaan Asuransi di Malang). Iqtishoduna, 6(2), 1-16.

[10] Quelch, J. A., \& Jocz, K. E. 2008. Milestones in Marketing. Business History Review, 82, 827-838. 